\title{
Generation of intracellular reactive oxygen species during the isolation of Brassica napus leaf protoplasts
}

\author{
Kaori Yasuda ${ }^{1}$, Yukio Watanabe ${ }^{2}$, Masami Watanabe ${ }^{2, *}$ \\ ${ }^{1}$ Graduate School of Science and Technology, Chiba University, Chiba 263-8522, Japan; ${ }^{2}$ Laboratory of Plant \\ Nutrition, Faculty of Horticulture, Chiba University, Chiba 271-8510, Japan \\ *E-mail: masamiwata@faculty.chiba-u.jp Tel \& Fax: +81-47-308-8820
}

Received February 16, 2007; accepted July 18, 2007 (Edited by K. Hiratsuka)

\begin{abstract}
The isolation of leaf protoplasts is a stress-inducing procedure that generates reactive oxygen species (ROS). We found that a cellulase-pectinase enzyme solution used for isolating protoplasts contained peroxidase (POX), catalase (CAT), and superoxide dismutase (SOD) activity, and effectively scavenged externally added hydrogen peroxides. During the isolation of Brassica napus leaf protoplasts, the protoplasts accumulated 1.5 times more intracellular $\mathrm{H}_{2} \mathrm{O}_{2}$ than normal leaf cells, but the $\mathrm{H}_{2} \mathrm{O}_{2}$ released into the medium increased only negligibly during culture. $\mathrm{H}_{2}$ DCF-DA and DAF2-DA were used as probes for the intracellular localization of $\mathrm{H}_{2} \mathrm{O}_{2}$ and $\mathrm{NO}$ with a confocal laser scanning system. $\mathrm{H}_{2} \mathrm{O}_{2}$ and $\mathrm{NO}$ had different intracellular localizations in freshly prepared B. napus leaf protoplasts. These results indicate that intracellular ROS are generated by the stresses of protoplast isolation and will induce the apoptosis-like cell death of the cultured protoplasts.
\end{abstract}

Key words: $\quad$ Apoptosis, Brassica napus, cell death, hydrogen peroxides, reactive oxygen species.

Cocking (1960) first reported a method for isolating plant protoplasts forty years ago. A decade later, a method for isolating plant mesophyll protoplasts was established once inexpensive cellulase and pectinase became commercially available in large quantities (Nagata and Takebe 1970). Plant protoplasts are not only an efficient experimental model for physiological and molecular studies but are also valuable tools for biotechnological applications, such as somatic hybridization and genetic transformation (for review, see (Vasil 1987)). Recently, the development of a protoplast transient expression system for high-throughput screening and systemic characterization of gene function has contributed to the elucidation of plant signal transduction pathways, in combination with genetic, genomic, and transgenic approaches (for review, see (Sheen 2002)).

Protoplasts are not merely cell wall-free replicates of the original cells. They undergo complex metabolic modification during their isolation and subsequent culture, because protoplast isolation requires the enzymatic removal of cell walls (Watanabe et al. 1998). Regeneration from protoplasts has been observed in only a limited number of the many plant species studied to date. Protoplasts of many important agricultural crops show recalcitrance in regeneration into whole plants.
Protoplast recalcitrance can occur at several points, including the initiation of cell division. Before plant regeneration can occur, protoplasts must undergo a process of dedifferentiation. Previously, we showed that Brassica napus leaf protoplasts initiate senescence during the isolation process and die via a process of apoptosis, similar to that observed in animal cells but with several morphological differences (Watanabe et al. 1998; Watanabe et al. 2002).

To date, there is no experimental evidence to explain why some protoplasts are recalcitrant and others regenerate. It is possible that the expression of this trait can be controlled by an elaborate network of genes. This might explain the observation that recalcitrance is linked to the genetic background of the donor plant. Given this hypothesis, the expression of totipotency may be controlled by signals that intervene before the expression of death-execution genes in the apoptotic process.

Programmed cell death (PCD) is the active process of cell death that occurs during development and in response to environmental signals (Greenberg 1996). The plant hypersensitive response (HR) functions to prevent the systemic spread of microbial pathogens and is thought to be a type of PCD. Fumonisin B1 toxin also induces cell death in Arabidopsis mesophyll protoplasts (Asai et al. 2000). Active oxygen species (ROS) play 
central roles in regulating PCD (Hammond-Kosack and Jones 1996) and have been addressed in several reviews (Lamb and Dixon 1997; Neil et al. 2002; Overmyer et al. 2003). The treatment of rice callus cells with xylanase and pectin lyase, both of which are components of commercial cellulase and pectinase preparations, generates superoxide radicals and causes cellular damage (Ishii 1987). ROS are also components of the hormonally regulated cell death pathway in barley aleurone protoplasts (Bethke and Jones 2001).

Hydrogen peroxide acts as a second messenger in plant systems: for example, in the induction of defense genes in tomato mesophyll cells (Orozco-Cardenas et al. 2001). Controlled levels of $\mathrm{H}_{2} \mathrm{O}_{2}$ are also necessary to allow proper cell-wall reconstitution and the consequent cell division (de Marco and Roubelakis-Angelakis 1996; Papadakis et al. 2001). Conversely, $\mathrm{H}_{2} \mathrm{O}_{2}$ from an oxidative burst was neither necessary nor sufficient to induce cell death (Dorey et al. 1999).

In view of the recalcitrance expressed at the point of cell division, and our interest in developing protoplast technology in important agricultural species, we examined the ROS generation in recalcitrant Brassica napus leaf protoplasts. This report will provides evidence for involvement of the intracellular oxidative burst in the apoptotic cell death response in $B$. napus leaf protoplasts.

\section{Materials and methods}

\section{Plant material and protoplast isolation and culture}

Seeds of B. napus L. cv. Bronowski were obtained from the National Institute of Agrobiological Resources (Tsukuba, Japan). Plants were grown under a 14-h photoperiod at a photon fluence density of $50 \mu \mathrm{mol} \mathrm{m}^{-2} \mathrm{~s}^{-1}$ from fluorescent tubes and on a day/night temperature cycle of $25 / 20^{\circ} \mathrm{C}$. Protoplasts were prepared from leaves of six- to eight-week-old plants, as described (Watanabe et al. 1992). Sterilized B. napus leaves were cut into narrow strips and incubated in an enzyme solution containing 1.0\% Cellulase Y-C (Kyowa Kasei, Osaka, Japan), 0.1\% Pectolyase Y-23 (Kyowa Kasei, Osaka, Japan), 5 $\mathrm{mM}$ MES (pH 5.8), and $0.6 \mathrm{M}$ sorbitol. The isolated protoplasts were cultured in six-well multidishes at $5 \times 10^{5}$ per well in MS medium (Murashige and Skoog 1962) supplemented with 4.5 $\mu \mathrm{M} 2,4-\mathrm{D}, 2.2 \mu \mathrm{M}$ BA, $2 \%$ sucrose, $1 \%$ glucose, and $0.5 \mathrm{M}$ sorbitol ( $\mathrm{pH} 5.8$ ). The bottom of each well was layered with $1.5 \%$ agar to prevent the adhesion of the protoplasts. The dishes were maintained in darkness at $25^{\circ} \mathrm{C}$.

\section{Protoplast viability assays}

Protoplast viability was monitored using Evans blue staining and a Nikon Eclipse TE300 inverted microscope (Nikon Co., Tokyo, Japan). Protoplasts were incubated in culture medium containing $0.01 \%(\mathrm{w} / \mathrm{v})$ Evans blue for $5 \mathrm{~min}$, and viable protoplasts were identified based on the exclusion of the stain (Graff and Okong O-Ogola 1971). The numbers of stained and unstained protoplasts were counted using a Fuchs-Rosenthal hemocytometer.

\section{Determination of intracellular $\mathrm{H}_{2} \mathrm{O}_{2}$}

B. napus leaves were divided into two parts: one part as a control and another to isolate protoplasts. Intracellular $\mathrm{H}_{2} \mathrm{O}_{2}$ was extracted using the method described by Rao (Rao et al. 2000). Briefly, frozen samples were homogenized with $1 \mathrm{~mL}$ of $0.2 \mathrm{M} \mathrm{HClO}_{4}$. The acidic extract was adjusted to $\mathrm{pH} 7.0-8.0$ with saturated $\mathrm{Na}_{2} \mathrm{CO}_{3}$ and centrifuged to sediment insoluble material. The colored components in the extract were removed by applying the extract to Dowex $1 \mathrm{X}-8$ resin (Muromachi Kagaku Kogyo, Tokyo, Japan) and eluting with Milli-Q ultrapure water. The $\mathrm{H}_{2} \mathrm{O}_{2}$ concentration was measured using the peroxidase-dependent assay described above.

\section{Determination of enzyme activities}

B. napus protoplasts were homogenized in a solution of $0.2 \mathrm{M}$ Tris- $\mathrm{HCl}$ ( $\mathrm{pH} 8.0$ ), $5 \mathrm{mM}$ dithiothreitol, $10 \mathrm{mM}$ ascorbate, 0.5 $\mathrm{mM}$ phenylmethylsulfonyl fluoride, and $0.1 \%(\mathrm{w} / \mathrm{v})$ Triton $\mathrm{X}-$ 100 using a mortar and pestle. The homogenates were centrifuged at $48000 \times g$ for $20 \mathrm{~min}$ and the supernatants were dialyzed against the above buffer. The dialyzed solution was subjected to determination of POX (EC 1.11.1.7), CAT (EC 1.11.1. 6), and total SOD (EC 1.15.1.1). The enzyme solution used for isolating protoplasts, containing 1.0\% Cellulase Y-C, $0.1 \%$ Pectolyase Y-23, $5 \mathrm{mM}$ MES ( $\mathrm{pH} 5.8$ ), and $0.6 \mathrm{M}$ sorbitol, was diluted and used for determination of POX, CAT, and SOD activity. The assay for POX activity was conducted in a total volume of $3.5 \mathrm{~mL}$ by mixing $1 \mathrm{~mL}$ of $0.2 \mathrm{M} \mathrm{K}$-phosphate buffer (pH 7.0), $1 \mathrm{~mL}$ of $1 \mathrm{mM}$-aminophenol, $1 \mathrm{~mL}$ of $4 \mathrm{mM}$ $\mathrm{H}_{2} \mathrm{O}_{2}$, and $0.5 \mathrm{~mL}$ of the dialyzed solution. The assay mixture was incubated at $25^{\circ} \mathrm{C}$ for $3 \mathrm{~min}$, and then $0.5 \mathrm{~mL}$ of $1 \mathrm{M} \mathrm{HCl}$ was added to terminate the reaction. The absorbance was then recorded at $480 \mathrm{~nm}$ with a spectrometer (U-1500, Hitachi). The amount of peroxidase that increased the absorbance by 1.0 at $480 \mathrm{~nm}$ was defined as one unit (Kawaoka et al. 1994).

The CAT activity was determined by measuring the initial rates of $\mathrm{H}_{2} \mathrm{O}_{2}$ decomposition at $240 \mathrm{~nm}$ in a solution containing $0.98 \mathrm{~mL}$ of $10 \mathrm{mM} \mathrm{H}_{2} \mathrm{O}_{2}$ in $50 \mathrm{mM} \mathrm{K}$-phosphate buffer ( $\mathrm{pH}$ 7.0) and $0.02 \mathrm{~mL}$ of the enzyme solution. One unit of CAT activity was defined as the amount of enzyme that catalyzed the conversion of $1 \mu \mathrm{mol}$ of $\mathrm{H}_{2} \mathrm{O}_{2} \mathrm{~min}^{-1}$ at $25^{\circ} \mathrm{C}$, using an $\varepsilon$ of $4.0 \times 10^{-5} \mu \mathrm{M} \mathrm{cm}^{-1}$ (Lück 1963).

The assay for SOD activity was based on the formation of nitrite from hydroxylamine in the presence of superoxide generators (Elstner and Heupel 1976). Briefly, reaction mixture \#1 consisted of $0.5 \mathrm{~mL}$ of the dialyzed solution, $1 \mathrm{~mL}$ of $65 \mathrm{mM}$ K-phosphate buffer ( $\mathrm{pH} 7.8$ ), $0.1 \mathrm{~mL}$ of $7.5 \mathrm{mM}$ xanthine, and $0.1 \mathrm{~mL}$ of $10 \mathrm{mM}$ hydroxylamine hydrochloride. The reaction was started by the addition of $0.3 \mathrm{~mL}$ of xanthine oxidase (40 $\mathrm{mU}$ ) and then incubated at $25^{\circ} \mathrm{C}$ for $20 \mathrm{~min}$. Next, $0.5 \mathrm{~mL}$ of reaction mixture \#1 was mixed with $0.5 \mathrm{~mL}$ of $19 \mathrm{mM}$ sulfonic acid and $0.5 \mathrm{~mL}$ of $7.0 \mathrm{mM} \alpha$-naphthylamine, and incubated at room temperature for $20 \mathrm{~min}$. The formation of nitrite was measured by monitoring the signal at $530 \mathrm{~nm}$. A standard absorbance curve was produced using known concentrations of nitrite.

\section{Luminol chemiluminescence assay}

Protoplast culture medium was centrifuged at low speed to 
remove protoplast cells, and the supernatant was recentrifuged at $27,000 \times g$ to remove cell debris. The resulting supernatant was used for $\mathrm{H}_{2} \mathrm{O}_{2}$ determination. $\mathrm{H}_{2} \mathrm{O}_{2}$ was quantified in terms of the chemiluminescence produced by the ferricyanidecatalyzed oxidation of luminol as described by Schwacke (Schwacke and Hager 1992), with slight modifications. Briefly, $10 \mu \mathrm{L}$ of the supernatant were mixed with $140 \mu \mathrm{L}$ of $0.05 \mathrm{M} \mathrm{K}$ phosphate buffer ( $\mathrm{pH} 7.9$ ) and $10 \mu \mathrm{L}$ of $1.1 \mathrm{mM}$ luminol in $0.05 \mathrm{M} \mathrm{K}$-phosphate buffer in a black 96-well plate. The chemiluminescence, recorded with a luminometer (MLR-100 Microluminoreader, Corona Electric, Hitachinaka, Japan), was integrated for the 30 -s period immediately after the start of the reaction. The $\mathrm{H}_{2} \mathrm{O}_{2}$ concentrations were determined from a standard graph generated using known amounts of $\mathrm{H}_{2} \mathrm{O}_{2}$.

For determination of the $\mathrm{H}_{2} \mathrm{O}_{2}$ scavenging potential of the enzyme solution for protoplast isolation, $\mathrm{H}_{2} \mathrm{O}_{2}$ was added to the enzyme solution containing $1.0 \%$ Cellulase Y-C, $0.1 \%$ Pectolyase Y-23, 0.6 M sorbitol, and 0.05 M K-phosphate buffer ( $\mathrm{pH}$ 7.9), and passed through an anion-exchange column (Super-Q Toyopearl 650S, Tosoh, Tokyo, Japan) equilibrated with $0.05 \mathrm{M} \mathrm{K}$-phosphate buffer $(\mathrm{pH}$ 7.9) to absorb colored proteins and prevent color quenching. Fifty $\mu \mathrm{L}$ of the resulting colorless eluate were mixed with $800 \mu \mathrm{L}$ of $0.05 \mathrm{M} \mathrm{K}$ phosphate buffer (pH 7.9) and $50 \mu \mathrm{L}$ of $1.1 \mathrm{mM}$ luminol (dissolved in $0.05 \mathrm{M}$ K-phosphate buffer) in a black tube. The luminescence was detected with a luminometer after the addition of $100 \mu \mathrm{L}$ of $7 \mathrm{mM}$ potassium ferricyanide over $10 \mathrm{~s}$ (Lumitester C-100, Kikkoman, Noda, Japan).

\section{Fluorometric analysis to localize intracellular $\mathrm{H}_{2} \mathrm{O}_{2}$ and $\mathrm{NO}$ production}

Intracellular $\mathrm{H}_{2} \mathrm{O}_{2}$ and $\mathrm{NO}$ production were measured by monitoring the fluorescence of dichlorofluorescein (DCF), which is the oxidation product of $\mathrm{H}_{2} \mathrm{DCF}$ (Allan and Fluhr 1997), and diaminofluorescein (DAF) (Kojima et al. 1998), respectively. 2', $7^{\prime}$-Dichlorofluorescein diacetate $\left(\mathrm{H}_{2} \mathrm{DCF}-\mathrm{DA}\right.$; Molecular Probes, Eugene, OR, USA) and diaminofluorescein2 diacetate (DAF-2DA; Daiichi Pure Chemicals, Tokyo, Japan) are cell-permeant indicators of ROS and NO that are nonfluorescent until the acetate groups are removed by intracellular esterases and oxidation occurs within the cells. The protoplasts were washed, resuspended in $0.6 \mathrm{M}$ sorbitol buffer ( $\mathrm{pH} 5.8$ ), and loaded with either $70 \mu \mathrm{M} \mathrm{H} \mathrm{H}_{2} \mathrm{DCF}-\mathrm{DA}$ for $30 \mathrm{~min}$ or 100 $\mu \mathrm{M}$ DAF-2DA for $60 \mathrm{~min}$ in darkness. After washing twice with $0.6 \mathrm{M}$ sorbitol, the fluorescence from DCF or DAF-2T and chlorophyll were observed at 494-559 and $680-730 \mathrm{~nm}$ emission wavelengths, respectively, using the 488-nm excitation wavelength in a Leica confocal laser scanning system (TCS-SP2; Leica Microsystems, Co., Tokyo, Japan).

\section{Statistics}

Data are reported as the mean \pm SD for the indicated experiments. The statistical significance of the differences was determined using one-way ANOVA, and multiple comparisons between mean values were analyzed using the Tukey honestly significant difference test. Statistical differences between the mean values were determined using the Dunnett test. All experiments were repeated at least three times.

\section{Results}

\section{ROS scavenging potential in the cellulase- pectinase enzyme solution used for isolating protoplasts}

Commercially obtained cellulase and pectinase are thought to be prepared as simple crude protein extracts. Therefore, solutions of these enzymes probably also contain radical scavenging activities. Table 1 shows that the enzyme solution used for the isolation of B. napus protoplasts, with 1\% Cellulase Y-C and $0.1 \%$ Pectolyase Y-23, also contains POX, CAT, and SOD activities.

$\mathrm{H}_{2} \mathrm{O}_{2}$ was added to the enzyme solution, and the $\mathrm{H}_{2} \mathrm{O}_{2}$ that remained after passing the solution through a SuperQ Toyopearl anion-exchange adsorbent to remove colored proteins was determined by luminol chemiluminescence. Table 2 shows that the freshly prepared enzyme solution contained a small amount of luminol-positive material, and that the addition of $\mathrm{H}_{2} \mathrm{O}_{2}$ to the enzyme solution affected this chemiluminescence level only slightly: the relative light unit (RLU) of luminol chemiluminescence increased by only $3 \%$. These results indicate that the exogenously supplied $\mathrm{H}_{2} \mathrm{O}_{2}$ was almost completely scavenged by the enzyme solution.

\section{Amount of hydrogen peroxide released during protoplast culture}

Both the amount of exogenous $\mathrm{H}_{2} \mathrm{O}_{2}$ released in the protoplast culture medium and the protoplast viability were monitored during the culture (Figure 1). The amount of $\mathrm{H}_{2} \mathrm{O}_{2}$ changed little during the course of the culture, but the viability gradually declined. This result indicates that the extracellular $\mathrm{H}_{2} \mathrm{O}_{2}$ released into the culture medium had little effect on the protoplast viability.

\section{Localization and quantification of intracellular $\mathrm{H}_{2} \mathrm{O}_{2}$}

Most cellular compartments have the potential to become

Table 1. Hydrogen peroxide and superoxide anion scavenging potential in an enzyme solution for protoplast isolation

\begin{tabular}{|c|c|c|}
\hline POX & CAT & SOD \\
\hline (Unit $\mathrm{mg}^{-1}$ protein) & (Unit $\mathrm{mg}^{-1}$ protein) & (Unit $\mathrm{mg}^{-1}$ protein) \\
\hline $73.46 \pm 2.47$ & $350.58 \pm 17.35$ & $1.78 \pm 0.01$ \\
\hline
\end{tabular}

Values are the means \pm SD of 4 replicates.

Table 2. Hydrogen peroxide scavenging potential in the enzyme solution for protoplast isolation.

\begin{tabular}{lcr}
\hline & Relative Light Unit (RLU) & $\%$ \\
\hline $100 \mu \mathrm{M} \mathrm{H}_{2} \mathrm{O}_{2}$ & $393 \pm 19.6$ & 100 \\
Enzyme Solution & $63 \pm 3.0$ & 16 \\
$100 \mu \mathrm{M} \mathrm{H}_{2} \mathrm{O}_{2}$ in Enzyme & $75 \pm 0.8$ & 19 \\
\hline
\end{tabular}

Values are the means \pm SD of 4 replicates. 
a source of ROS. We compared the intracellular $\mathrm{H}_{2} \mathrm{O}_{2}$ level in B. napus with that in regenerating Petunia hybrida leaf protoplasts. B. napus leaf protoplasts are recalcitrant to the initiation of cell division; in contrast, petunia leaf protoplasts are totipotent. The intracellular $\mathrm{H}_{2} \mathrm{O}_{2}$ contents in petunia and B. napus leaves and leaf protoplasts were determined (Table 3). Petunia leaves and their protoplasts generated the same level of intracellular $\mathrm{H}_{2} \mathrm{O}_{2}$, whereas the intracellular $\mathrm{H}_{2} \mathrm{O}_{2}$ level in B. napus leaf protoplasts was 1.5 times that in leaves.

$\mathrm{H}_{2}$ DCF-DA and DAF-2DA, chemical probes for $\mathrm{H}_{2} \mathrm{O}_{2}$ and $\mathrm{NO}$, were used to detect intracellular $\mathrm{H}_{2} \mathrm{O}_{2}$ and $\mathrm{NO}$ formation in $B$. napus leaf protoplasts by visualization using a Leica confocal microscope. NADH-dependent oxidase (NADPH oxidase) on the plasma membrane is regarded as a source of ROS for the oxidative burst (Lamb and Dixon 1997). The NADPH oxidase is activated by a calcium influx and inhibited by

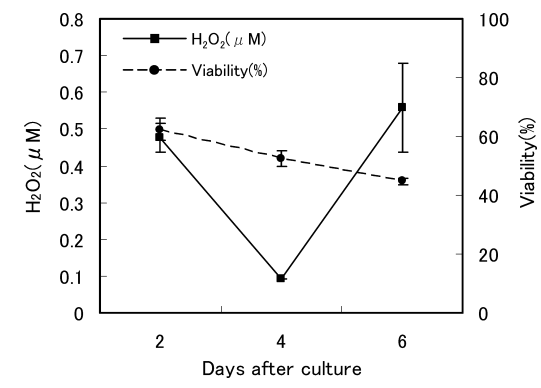

Figure 1. Quantification of extracellular $\mathrm{H}_{2} \mathrm{O}_{2}$ in the medium and changes in viability during the culture of $B$. napus leaf protoplasts. $B$. napus leaf protoplasts in Murashige Skoog (MS) liquid medium were precipitated by centrifugation. The supernatant was further centrifuged at high speed for removal of cellular debris. The resulting supernatant was used to measure the levels of extracellular $\mathrm{H}_{2} \mathrm{O}_{2}$ by luminol. Viability of B. napus leaf protoplasts was determined by counting the numbers of protoplasts stained with Evans Blue dye . Values are the means $\pm \mathrm{SD}$ of four replicates. diphenylene iodonium (DPI).

Protoplasts were isolated in the presence of $10 \mu \mathrm{M}$ DPI or $100 \mu \mathrm{M}$ PTIO and stained with $70 \mu \mathrm{M} \mathrm{H}_{2}$ DCFDA or $100 \mu \mathrm{M}$ DAF-2DA (Figure 2). DPI, an inhibitor of NADPH oxidase, which is bound to the plasma membrane, could not effectively scavenge DCF fluorescence (Figure 2A), whereas Tiron and PTIO, scavengers of ROS and NO, respectively, efficiently eliminated ROS and NO (Figure 2E, I). Figures $2 \mathrm{C}$ and $\mathrm{G}$ show that DCF fluorescence was high in both cytoplasm and chloroplasts of B. napus, and DAF-2T fluorescence was high in cytoplasm. To confirm that the chloroplasts were the sites of $\mathrm{H}_{2} \mathrm{O}_{2}$ and $\mathrm{NO}$ production, chloroplasts were visualized using chlorophyll autofluorescence (Figure 2B, D, F, H). The intracellular locations of $\mathrm{H}_{2} \mathrm{O}_{2}$ and $\mathrm{NO}$ generation differed. In addition, several confocal images along the $z$-axis direction were obtained to detect the sites of $\mathrm{H}_{2} \mathrm{O}_{2}$ and NO formation in cells (data not shown). However, it was not possible obtain an image in which only mitochondria were stained with either $\mathrm{H}_{2}$ DCF-DA or DAF2-DA.

\section{Discussion}

The enzyme-mediated digestion of cell walls, which is required to isolate protoplasts, results in the formation of

Table 3. Changes in intracellular $\mathrm{H}_{2} \mathrm{O}_{2}$ levels during the isolation of Petunia hybrida and Brassica napus leaf protoplasts.

\begin{tabular}{ccc}
\hline & \multicolumn{2}{c}{ Intracellular $\mathrm{H}_{2} \mathrm{O}_{2}\left(\mathrm{nmol} \mathrm{mg}^{-1} \mathrm{Chl}\right)$} \\
& Brassica napus & Petunia hybrida \\
\hline Protoplasts & $51.7^{\mathrm{a}} \pm 2.25$ & $27.0 \pm 3.41$ \\
Leaves & $34.8 \pm 4.94$ & $24.2 \pm 3.31$ \\
\hline
\end{tabular}

Values are the means \pm SD of 4 replicates. ${ }^{\text {a }}$ Indicates the values that are significantly different from leaves at $P<0.01$ according to the Dunnett test.

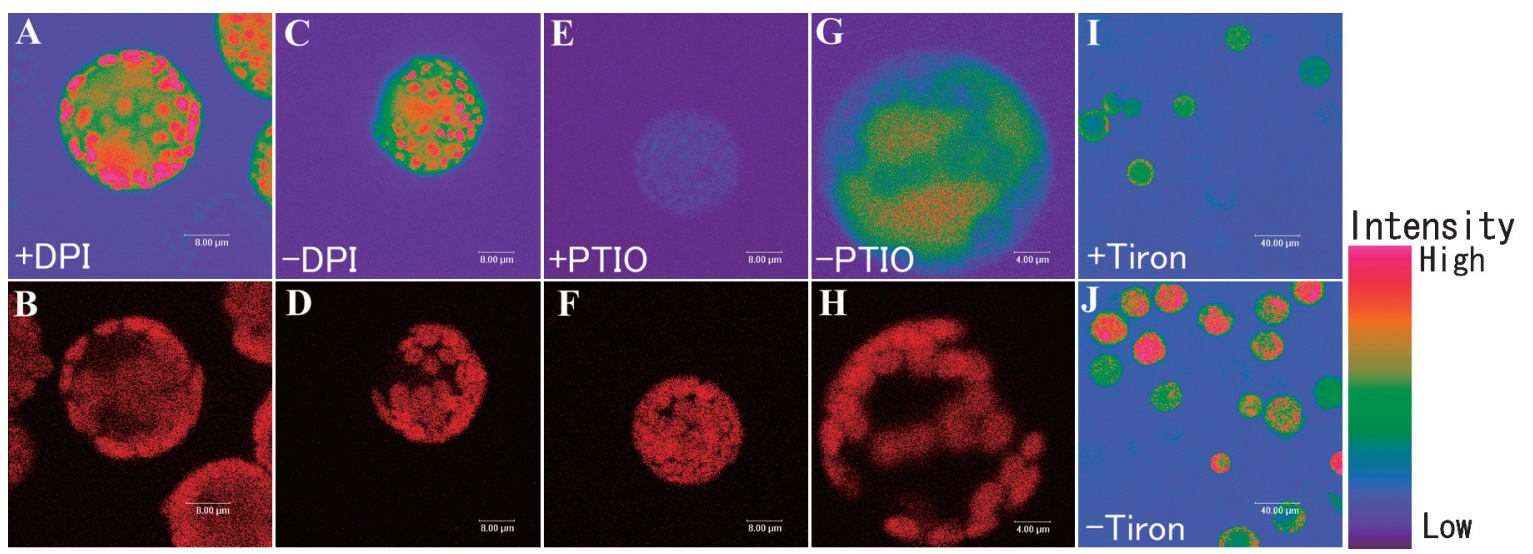

Figure 2. Imaging of $\mathrm{H}_{2} \mathrm{O}_{2}$ and $\mathrm{NO}$ in Brassica napus leaf protoplasts visualized using a Leica confocal laser scanning system (TCS-SP2). The protoplasts were isolated with addition of $10 \mu \mathrm{M}$ diphenylene iodonium (DPI) or $100 \mathrm{mM}$ 1,2-Dihydroxy-3,5-benzenedisulfonic acid (Tiron) and stained with $70 \mu \mathrm{M}$ 2', 7'-dichlorodihydrofluorescein diacetate (H2DCF-DA) (A, B, I), or addition of 100 $\mu \mathrm{M}$ 2-Phenyl-4,4,5,5tetramethylimidazoline-1-oxyl 3-oxide (PTIO) and stained with $100 \mu \mathrm{M}$ diaminofluoresxein-2 diacethyl (DAF-2DA) (E, F). The protoplasts were isolated without DPI or Tiron and stained with $70 \mu \mathrm{M} \mathrm{H}_{2}$ DCF-DA for $\mathrm{H}_{2} \mathrm{O}_{2}(\mathrm{C}, \mathrm{D}, \mathrm{J})$, and isolated without PTIO and stained with DAF-2DA for NO $(\mathrm{G}, \mathrm{H})$. Chloroplasts were visualized by the autofluorescence (B, D, F, H). The bars represents $8.0 \mu \mathrm{m}(\mathrm{A} \sim \mathrm{F}), 4.0 \mu \mathrm{m}(\mathrm{G}, \mathrm{H})$ and $40 \mu \mathrm{m}(\mathrm{I}, \mathrm{J})$. 
both superoxide and hydrogen peroxide (Ishii 1987). Use of xylanase-containing unpurified cellulase induced a burst of $\mathrm{O}_{2}^{-}$and $\mathrm{H}_{2} \mathrm{O}_{2}$ accumulation in tobacco leaf strips (Papadakis and Roubelakis-Angelakis 1999). Antisense knockouts and gene silencing in tobacco and an analysis of Arabidopsis mutants have confirmed the role of NADPH oxidase as the source of $\mathrm{O}_{2}^{-}$in the oxidative burst that regulates cell death (Simon-Plas et al. 2002; Torres et al. 2002; Yoshioka et al. 2003). $\mathrm{H}_{2} \mathrm{O}_{2}$ is stable and immediately formed from $\mathrm{O}_{2}^{-}$by spontaneous or SOD-catalyzed dismutation. Therefore, we focused on $\mathrm{H}_{2} \mathrm{O}_{2}$ instead of $\mathrm{O}_{2}^{-}$. If NADPH oxidase, which mediates hypersensitive cell death, is activated during the isolation of $B$. napus leaf protoplasts, $\mathrm{H}_{2} \mathrm{O}_{2}$ will be released into the isolation medium. However, $\mathrm{H}_{2} \mathrm{O}_{2}$ was effectively scavenged by POX and CAT contamination in the cellulase-pectinase enzyme solution as soon as the $\mathrm{H}_{2} \mathrm{O}_{2}$ was released (Tables 1,2).

Blocking the activity of NADPH oxidase with diphenylene iodonium (DPI) inhibits ROS formation (Alvarez et al. 1998), and NADPH oxidase is activated by $\mathrm{O}_{2}^{+}$(Jabs et al. 1997). However, DPI did not effectively scavenge DCF fluorescence (Figure 2A, C). Since plant cells contain many sources of ROS, pathways other than the NADPH oxidase-dependent pathway may be involved in ROS production during the isolation of $B$. napus leaf protoplasts. Since $B$. napus leaf protoplasts generate and release little extracellular $\mathrm{H}_{2} \mathrm{O}_{2}$ during culture, and their viability declined only gradually (Figure 1), it is thought that the PCD decision is made during the protoplast isolation procedure. Then, the intracellular $\mathrm{H}_{2} \mathrm{O}_{2}$ levels in B. napus and P. hybrida leaves and protoplasts were compared (Table 3). The amount of intracellular $\mathrm{H}_{2} \mathrm{O}_{2}$ was 1.5 -fold higher in $B$. napus leaf protoplasts than in intact leaves, whereas that in petunia protoplasts was the same as in leaves. Petunia leaf protoplasts have the potential to initiate cell division. In contrast, an imbalance of intracellular ROS may induce apoptosis in B. napus leaf protoplasts.

Apoptosis is a defined series of cellular processes that are typically triggered by mitochondrial events in animal cells (Earnshaw 1999). The ubisemiquinone radical in the mitochondrial electron transport chain can transfer a single electron to oxygen and produce $\mathrm{O}_{2}^{-}$. Recent evidence has implicated ROS as direct and indirect mediators of PCD, and mitochondria have key roles in the apoptotic processes in plant and animal cells (Jabs 1999). Although little is known about the commonality of mitochondria as a factor in PCD, the mitochondrial oxidative burst and mitochondrial transmembrane potential breakdown are involved in the induction of victorin-induced apoptosis-like cell death in oats (Yao et al. 2002).

Another intracellular source of ROS is chloroplasts. The involvement of chloroplast-mediated ROS in the induction of the apoptotic response in plants has not been demonstrated. Intracellular ROS cannot be extracted from homogenized cells and determined using disruptive biochemical methods because ROS are released and scavenged immediately at the time of cellular degradation. Therefore, $\mathrm{H}_{2}$ DCF-DA, a specific probe for intracellular $\mathrm{H}_{2} \mathrm{O}_{2}$, was used to trap the intracellular $\mathrm{H}_{2} \mathrm{O}_{2}$. The use of $\mathrm{H}_{2}$ DCF-DA revealed that the generation of $B$. napus leaf protoplasts elicits a burst of $\mathrm{H}_{2} \mathrm{O}_{2}$ from chloroplasts as well as cytoplasm (Figure 2A, C). H2DCF-DA has also been reported to react with peroxynitrite $\left(\mathrm{ONOO}^{-}\right)$, the reaction product of nitric oxide and superoxide, two potent reactive species (Possela et al. 1997). DAF2-DA, a probe specific for NO, was used and the fluorescence images compared (Figure 2C, G). When either Tiron or PTIO, scavengers of ROS and NO, respectively, were added to the protoplast isolation medium, the fluorescence completely disappeared. However, DPI did not inhibit $\mathrm{H}_{2} \mathrm{O}_{2}$ generation. These results indicate that the plasma membrane-binding NADPH oxidase did not generate $\mathrm{H}_{2} \mathrm{O}_{2}$, but that the cytoplasm produced $\mathrm{NO}, \mathrm{ONOO}^{-}$, and $\mathrm{H}_{2} \mathrm{O}_{2}$, and the chloroplasts generated $\mathrm{H}_{2} \mathrm{O}_{2}$. Under nonstressed conditions, when the photon intensity is within the range of the utilizing capacity of chloroplasts for $\mathrm{CO}_{2}$ fixation, the rate of ROS generation is kept very low by scavenging enzymes and other antioxidants (Asada 1999). Since the leaf protoplasts were isolated under light conditions, they were not thought to accumulate ROS in chloroplasts during their isolation. In contrast, the B. napus leaf protoplasts produced large amounts of ROS in chloroplasts during isolation, and were certainly under some type of stress. Therefore, ROS produced during isolation would affect other cellular compartments (such as mitochondria), as well as overwhelm their ROS scavenging capabilities, alter the pattern of gene expression, and lead to the apoptosis of B. napus leaf protoplasts.

Although many questions remain concerning the induction, regulation, and execution of apoptosis in plant cells, our data will suggest that an overdose of ROS in the cytoplasm and chloroplasts induces apoptotic cell death in B. napus leaf protoplasts.

\section{References}

Allan AC, Fluhr R (1997) Two distinct sources of elicited reactive oxygen species in tobacco epidermal cells. Plant Cell 9: $1559-1572$

Alvarez ME, Pennell RI, Meijer PJ, Ishikawa A, Dixon RA, Lamb C (1998) Reactive oxygen intermediates mediate a systemic signal network in the establishment of plant immunity. Cell 92: 773-784

Asada K (1999) The water-water cycle in chloroplasts: Scavenging of active oxygens and dissipation of excess photons. Annu Rev Plant Physiol Plant Mol Biol 50: 601-639 
Asai T, Stone JM, Heard JE, Kovtun Y, Yorgey P, Sheen J, Ausubel FM (2000) Fumonisin B1-induced cell death in Arabidopsis protoplasts requires jasmonate-, ethylene-, and salicylatedependent signaling pathways. Plant Cell 12: 1823-1836

Bethke PC, Jones RL (2001) Cell death of barley aleurone protoplasts is mediated by reactive oxygen species. Plant $J 25$ : 19-29

Cocking EC (1960) A method for the isolation of plant protoplasts and vacuoles. Nature 187: 927-929

de Marco A, Roubelakis-Angelakis KA (1996) The complexity of enzymic control of hydrogen peroxide concentration may affect the regeneration potential of plant protoplasts1. Plant Physiol 110: $137-145$

Dorey S, Kopp M, Geoffroy P, Fritig B, Kauffmann S (1999) Hydrogen peroxide from the oxidative burst is neither necessary nor sufficient for hypersensitive cell death induction, phenylalanine ammonia lyase stimulation, salicylic acid accumulation, or scopoletin consumption in cultured tobacco cells treated with elicitin. Plant Physiol 121: 163-172

Earnshaw WC (1999) Apoptosis. A cellular poison cupboard. Nature 397: 387-389

Elstner EF, Heupel A (1976) Inhibition of nitrite formation from hydroxylammoniumchloride: a simple assay for superoxide dismutase. Anal Biochem 70: 616-620

Graff DF, Okong O-Ogola O (1971) The use of non-permeating pigments for testing the survival of cells. $J$ Exp Bot 22: 756-758

Greenberg JT (1996) Programmed cell death: A way of life for plants. Proc Natl Acad Sci USA 93: 12094-12097

Hammond-Kosack KE, Jones JDG (1996) Resistance genedependent plant defense responses. Plant Cell 8: 1773-1791

Ishii S (1987) Generation of active oxygen species during enzymic isolation of protoplasts from oat leaves. In Vitro 23: 653-658

Jabs T (1999) Reactive oxygen intermediates as mediators of programmed cell death in plants and animals. Biochem Pharmacol 57: 231-245

Jabs T, Tschöpe M, Colling C, Hahlbrock K, Scheel D (1997) Elicitor-stimulated ion fluxes and $\mathrm{O}_{2}^{-}$from the oxidative burst are essential components in triggering defense gene activation and phytoalexin synthesis in parsley. Proc Natl Acad Sci USA 94: 4800-4805

Kawaoka A, Kawamoto T, Ohta H, Sekine M, Takano M, Shinmyo A (1994) Wound-induced expression of horseradish peroxidase. Plant Cell Rep 13: 149-154

Kojima H, Nakatsubo N, Kikuchi K, Kawahara S, Kirino Y, Nagoshi H, Hirata Y, Nagano T (1998) Detection and Imaging of Nitric Oxide with Novel Fluorescent Indicators: Diaminofluoresceins. Anal Chem 70: 2446-2453

Lamb C, Dixon RA (1997) The oxidative burst in plant disease resistance. Annu Rev Plant Physiol Plant Mol Biol 48: 251-275

Lück H (1963) Catalase. In: Bergmeyer HU (ed) Methods of Enzymatic Analysis. Academic Press, New York, pp 885-894

Murashige T, Skoog F (1962) A revised medium for rapid growth and bio assays with tobacco tissue cultures. Physiol Plant 15: 473-497

Nagata T, Takebe I (1970) Cell wall regeneration and cell division in isolated tobacco mesophyll protoplasts. Planta 92: 301-308
Neil SJ, Desikan R, Clarke A, Hurst R, Hancock JT (2002) Hydrogen peroxide and nitric oxide as signaling molecules in plants. J Exp Bot 53: 1237-1247

Orozco-Cardenas M, Narvaez-Vasquez J, Ryan C (2001) Hydrogen peroxide acts as a second messenger for the induction of defense genes in tomato plants in response to wounding, systemin, and methyl jasmonate. Plant Cell 13: 179-191

Overmyer K, Brosche M, Kangasjarvi J (2003) Reactive oxygen species and hormonal control of cell death. Trends Plant Sci 8: 335-342

Papadakis AK, Roubelakis-Angelakis KA (1999) The generation of active oxygen species differs in tobacco and grapevine mesophyll protoplasts. Plant Physiol 121: 197-206.

Papadakis AK, Siminis CI, Roubelakis-Angelakis KA (2001) Reduced activity of antioxidant machinery is correlated with suppression of totipotency in plant protoplasts. Plant Physiol 126: 434-444.

Possela H, Noacka H, Augustinb W, Keilhoffa G, Wolfa G (1997) 2,7-Dihydrodichlorofluorescein diacetate as a fluorescent marker for peroxynitrite formation. FEBS Lett 416: 175-178

Rao MV, Lee H, Creelman RA, Mullet JE, Davis KR (2000) Jasmonic acid signaling modulates ozone-induced hypersensitive cell death. Plant Cell 12: 1633-1646

Schwacke R, Hager A (1992) Fungal elicitors induce a transient release of active oxygen species from cultured spruce cells that is dependent on $\mathrm{Ca}^{2+}$ and protein-kinase activity. Planta 187 : $136-141$

Sheen J (2002) Signal transduction in maize and arabidopsis mesophyll protoplasts1. Plant Physiol 127: 1466-1475

Simon-Plas F, Elmayan T, Blein JB (2002) The plasma membrane oxidase NtrbohD is responsible for AOS production in elicited tobacco cells. Plant J31: 137-147

Torres MA, Jeffery L, Dangl JL, Jones JDG (2002) Arabidopsis gp91phox homologues AtrbohD and AtrbohF are required for accumulation of reactive oxygen intermediates in the plant defense response. Proc Natl Acad Sci USA 99: 517-522

Vasil IK (1987) Developing cell and tissue culture systems for the improvement of cereal and grass crops. J Plant Physiol 128: 193-218

Watanabe M, Hanamoto T, Watanabe Y (1998) Senescence development of Brassica napus leaf protoplast during isolation and subsequent culture. J Plant Physiol 152: 487-493

Watanabe M, Nakayama H, Watanabe Y, Shimada N (1992) Induction of a specific isoenzyme of glutamate dehydrogenase during isolation and the first $48 \mathrm{~h}$ of culture of Brassica napus leaf protoplasts. Physiol Plant 86: 231-235

Watanabe M, Setoguchi D, Uehara K, Ohtsuka W, Watanabe Y (2002) Apoptotic-like cell death of Brassica napus leaf protoplasts. New Phytol 156: 417-426

Yao N, Tada Y, Sakamoto M, Nakayashiki H, Park P, Tosa Y, Mayama S (2002) Mitochondrial oxidative burst involved in apoptotic response in oats. Plant J 30: 567-579

Yoshioka H, Numata N, Nakajima K, Katou S, Kawakita K, Rowland O, Jones JDG, Doke N (2003) Nicotiana benthamiana gp91phox homologs NbrbohA and NbdbohB participate in $\mathrm{H}_{2} \mathrm{O}_{2}$ accumulation and resistance to Phytophthora infestans. Plant Cell 15: 706-718 